\title{
Immunology and Immunotherapy
}

\section{COVID-19: A Cure and Preventive Options}

\author{
Dr. Roli Jain* and Dr. Archana Panday
}

Department of Chemistry, Dr. Harisingh Gour Central University, India

*Corresponding author: Dr. Roli Jain, Department of Chemistry, Dr. Harisingh Gour Central University, India

\begin{abstract}
The world experienced the outbreaks of coronavirus infection that threaten global pandemic in 2002-2003 by Severe Acute Respiratory Syndrome (SARS) and in 2011 by Middle East Respiratory Syndrome (MERS). The genomic sequence of SARS-CoV-2 showed similar, but distinct genome composition of SARS-CoV and MERS-CoV [1,2].

On an average corona hit the $1.5 \%$ to 2020 global GDP and $0.2 \%$ to long-run global GDP. We forecast a muted longterm impact because damage to productive capacity will be small, plus economic confidence should quickly return once the virus subsides.

The body's immune system is, at the moment, the most effective weapon people have against COVID-19. The majority of patients can cure themselves of the disease simply by resting at home - enabling a small army of their own cells to attack the infection.

The some antiviral, anti-malarial, spiked protein based vaccine and antibody plasma therapies as a cure and phytochemical, stronger immune system and guideline given by health agencies discussed as a preventive approach discussed in this article.
\end{abstract}

\section{Keywords}

COVID-19, Antiviral, Anti-inflammatory, Anti-malarial drugs, Blood plasma, Antibody, Phytochemical, Nutraceutical, WHO, CDC

\section{Introduction}

The world encounters the episode of coronavirus infection that undetermined worldwide pandemic in 2002-2003 by Severe Acute Respiratory Syndrome (SARS) and in 2011 by Middle East Respiratory Syndrome (MERS). The genomic sequence of SARS-CoV-2 indicate similar, but distinct genome composition of SARSCoV and MERS-CoV [1,2].

The unpreceded virus has recently emerged as a human pathogen in the city of Wuhan in China's Hubei province, causing fever, severe respiratory ailment, and pneumonia illness recently named COVID-19 [3,4].

The World Health Organization (WHO) also declared a global emergency on January $31^{\text {st }}$ due to increasing concerns over its fast spread, and on March $11^{\text {th }}$ the disease was recognized as a pandemic.

In general coronaviruses cause across the broad respiratory, gastrointestinal, and central nervous system diseases in humans and other animals, threatening human health and causing economic loss $[5,6]$. Coronaviruses are capable for adjusting with environment through the transformation and recombination without hardly lifting a finger and consequently are customized to modify have range and tissue tropism effectively $[7,8]$. Along these lines, wellbeing dangers from coronaviruses are steady and long haul. Understanding the virology of coronaviruses and controlling their spread have significant ramifications for worldwide wellbeing and financial stability.

Conventionally the corona hit $1.5 \%$ to 2020 worldwide GDP and $0.2 \%$ to long-run global GDP. We estimate a quieted long-haul impact because damage to productive capacity will be small in addition to financial certainty ought to rapidly return once the infection dies down [911] (Figure 1).

In this article writer examine about how this infection assault on the human body and what are the preventive methodologies and treatment are accessible to defeat with this circumstance. Here we can likewise see how the human insusceptible framework respond towards SARS COV- 2 and examine about the conceivable anticipation and cerement choices like phytochemicals, Nutraceutical fixings, antiviral medication and immunizations [12]. 
Exposure to global supply chains could be crucial to the length of time it takes sectors and countries to recover

Export exposure

(Exports of goods and services as a \% of GDP, latest year available)

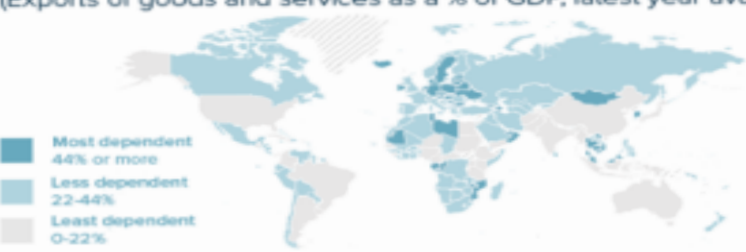

Global health epidemic preparedness vs export exposure

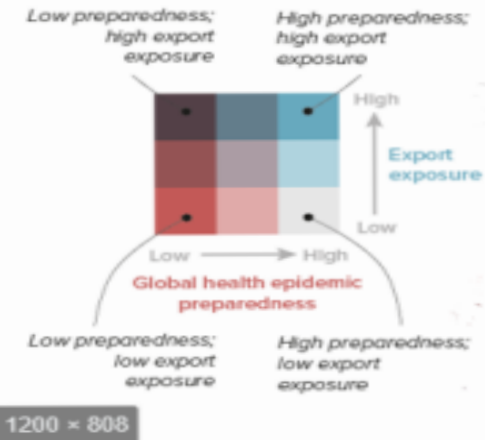

Global health epidemic preparedness, 2019

(Global health security index, $0-100$, where 100 is best)

Figure 1: Health preparedness and trade affect COVID-19 exposure [11].

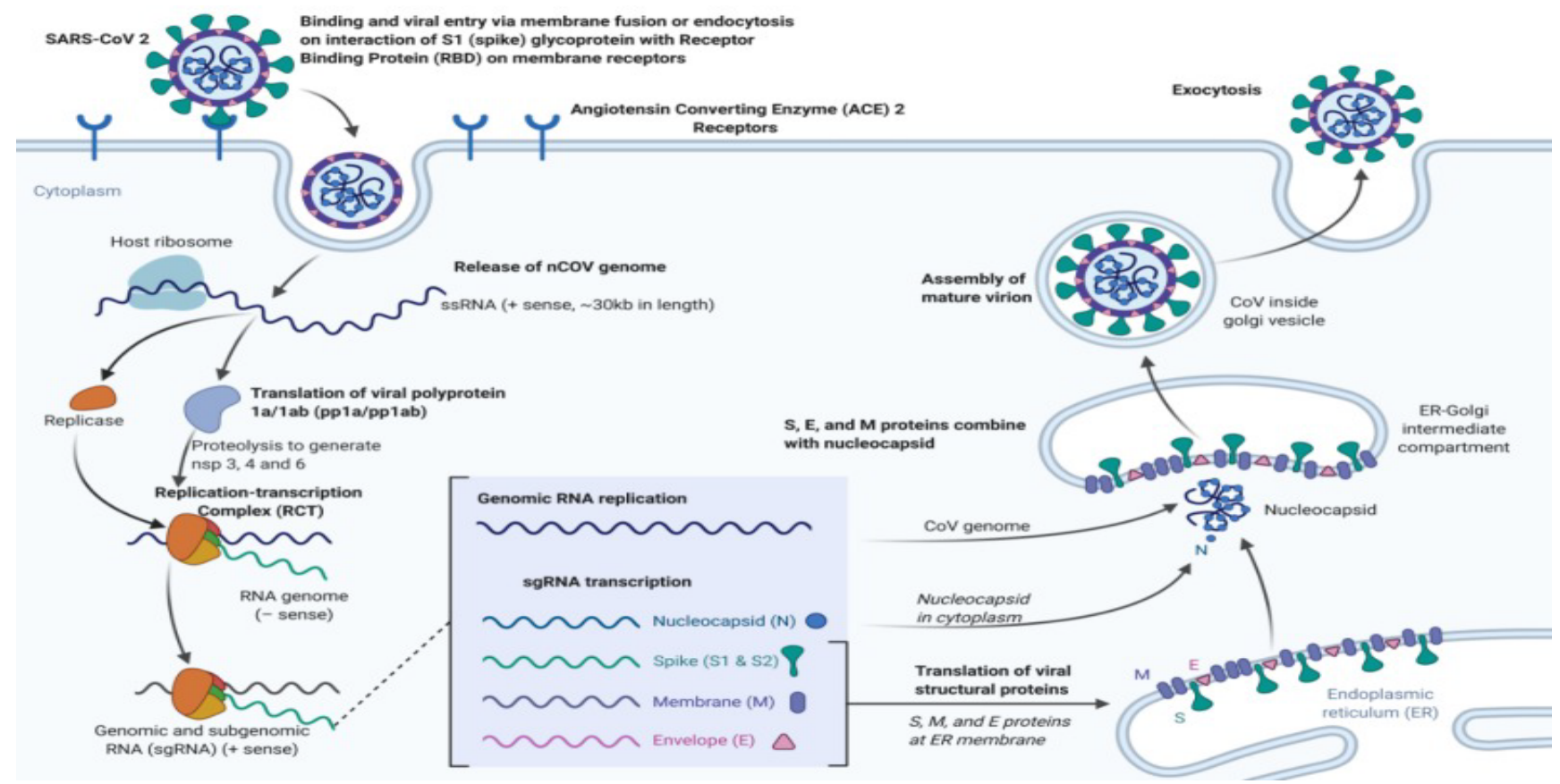

Figure 2: The systemic illustration of mechanism of entry of corona virus in host cell [17].

\section{Mechanism of SARS-COV-2 in Host Cell}

Coronaviruses are large, wrapped, positive-stranded RNA infections. They have the biggest genome among all RNA infections, ordinarily extending from 27 to 32 $\mathrm{kb}$. The genome is content inside a helical capsid shaped by the Nucleocapsid Protein $(\mathrm{N})$ and assist encompassed by an envelope. Related with the viral envelope are at slightest three auxiliary proteins: The Membrane Protein (M) and the Envelope Protein (E) are included in infection get together, while the Spike Protein (S) intervenes infection section into host cells [13].
The S protein has three major sections which are the large ectodomain, a single-pass transmembrane anchor and a short intracellular tail. These play a major role in anchoring the host cells. Among these sections have two subunits which are the S1 receptor-binding subunit and $\mathrm{S} 2$ the membrane fusion subunit [14].

The interaction between S1 domain and its cognate receptor initiate the conformational change in the $S$ protein that's leads to conformational change between the viral and cell layer through the S2 domin. This infection recognized the exopeptidases. The entry mechanism depends on the cellular proteases which incorpo- 
rate, human aviation route trypsin-like protease (Cap), catharsis and Trans Film Protease serine 2 (TMPRSS2) that part the spike protein and build up advance entrance. The Angiotensin-Converting Chemical 2 (ACE2) working as a key receptor in the host cell. The $2^{\text {nd }}$ step is the replication that starts with the interpretation of ORF1a and $1 \mathrm{~b}$ into the poly-proteins pp1a (4382 amino corrosive) and pp 1ab (7073 amino corrosive) and downstream ORF1by the ribosomal outline move in instrument. The systemic outline of component of passage of crown infection outlined in (Figure 2).

By the method of apoptosis infection taint the human wellbeing cell. Regularly this infection majorly affects the breath track this handle due to the cytokine release disorder could be a imperative calculate that disturbs infection movement. The next levels of IL- 6 and $\mathrm{IL}-10$, and lower levels of CD4+T and CD8+T are watched in COVID-19 patient's parallel with the seriousness of the disease [15-17].

\section{Mechanism of Immune System of Host cell}

The body's immune system is, at the moment, the most effective weapon people have against COVID-19. The majority of patients can cure themselves of the disease simply by resting at home - enabling a small army of their own cells to attack the infection. Those cells make it harder for the virus to replicate, and help to develop antibodies that prevent it from infecting new cells.

In general, the Th1 type immune response plays a dominant role in an adaptive immunity to viral in- fections. Cytokine microenvironment generated by antigen presenting cells dictates the direction of $T$ cell responses. Helper T cells orchestrate the overall adaptive response, while cytotoxic T cells are essential in killing of viral infected cells. Humeral immune response, especially production of neutralizing antibody, plays a protective role by limiting infection at later phase and prevents re- infection in the future. In SARS-CoV, both $T$ and $B$ cell epitopes were extensively mapped for the structural proteins, S, N, M and E protein [11]. Immune responses in COVID-19 and potential vaccines: Lessons learned from SARS and MERS epidemic.

Exactly why or how COVID-19 would do the same remains unclear. But data suggest that patients have elevated levels of cytokines and other immune molecules that are associated with these storms. It's possible that the cytokine storm is being triggered because the virus is continuing to replicate.

Here T-cells take place an important role to, build up in the body again. As they do, patients could start to improve [18-20] (Figure 3).

In addition, the study of 41 hospitalized patients with high-levels of proinflammatory cytokines including IL-2, IL-7, IL-10, G-CSF, IP-10, MCP-1, MIP-1A, and TNF $\alpha$ were observed in the COVID-19 severe cases [21].

\section{Therapeutic Strategies against COVID-19}

Since SARS-CoV-2 is a newly discovered pathogen, no specific drugs have been identified or are currently

\section{Immune system overdrive}

While the mechanism that causes the most severe effects of COVID-19 is yet to be fully understood, some scientists have suggested that a hyperactive response from a patient's own defence mechanism can cause fatal damage

\section{Cytokine storm}

The immune response goes into overdrive

- Documented in influenza, SARS and MERS patients

- Also associated with non-infectious diseses such as multiple sclerosis and pancreatitis
Protective response

Immune cells arrive at the site of infection but do not overwhelm

\section{Overactive response}

Uncontrolled levels of cytokines activate too many immune cells, leading to hyperinflammation

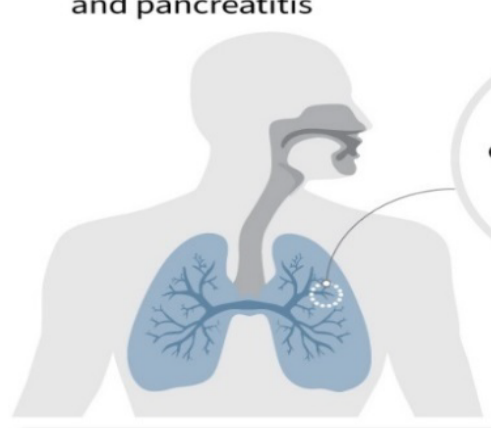

Cytokine molecules stimulate the movement of cells towards sites of inflammation, infection and trauma

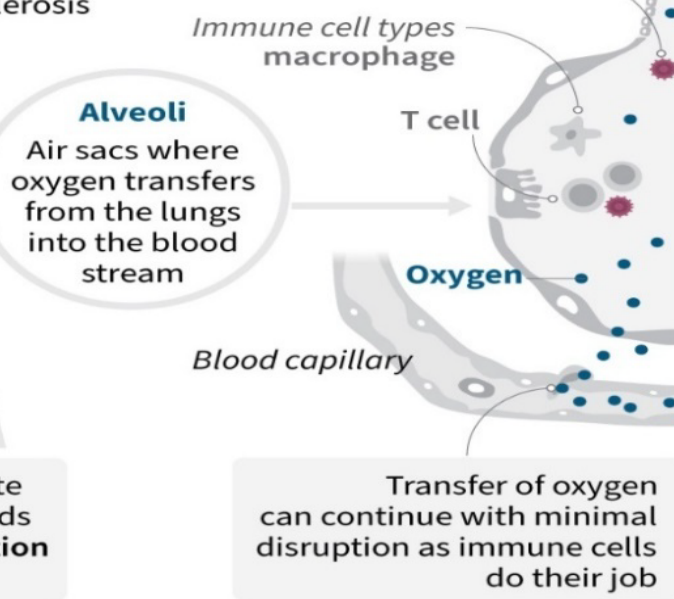

Figure 3: Response of Immune system toward respiratory illness ny COVID-19 [19]. 
Table 1: Existing drugs with therapeutic potentials for COVID-19 (Drug Repurposing) [26-32].

\begin{tabular}{|l|l|l|l|}
\hline Drug candidate & Target & Mechanism of Action on COVID-19 & Drug category \\
\hline Baricitinib & JAK kinase & A JAK inhibitor & $\begin{array}{l}\text { Rheumatoid arthritis/Anti- } \\
\text { inflammatory }\end{array}$ \\
\hline Lopinavir & Viral proteases: 3CLpro & $\begin{array}{l}\text { Protease inhibitors that may inhibit the } \\
\text { viral proteases: 3CLpro or PLpro }\end{array}$ & HIV infection \\
\hline Ritonavire & $\begin{array}{l}\text { Vviral proteases: 3CLpro } \\
\text { or PLpro }\end{array}$ & $\begin{array}{l}\text { Protease inhibitors that may inhibit the } \\
\text { viral proteases: 3CLpro or PLpro }\end{array}$ & HIV infection \\
\hline Favipiravir (favilavir) & RdRp & $\begin{array}{l}\text { A purine nucleoside that acts as an } \\
\text { alternate substrate leading to inaccurate } \\
\text { viral RNA synthesis }\end{array}$ & Viral infections \\
\hline Remdesivir & $\begin{array}{l}\text { A nucleotide analogue that may block } \\
\text { viral nucleotide synthesis to stop viral } \\
\text { replication }\end{array}$ & Ebola virus infection \\
\hline Arbidol & S protein/ACE2d & $\begin{array}{l}\text { An inhibitor that may disrupt the binding } \\
\text { of viral envelope protein to host cells and } \\
\text { prevent viral entry to the target cell }\end{array}$ & Influenza antiviral drug \\
\hline Chloroquine & Endosome/ACE2 & $\begin{array}{l}\text { A drug that can elevate endosomal pH } \\
\text { and interfere with ACE2 glycosylation }\end{array}$ & Malarial parasite infection \\
\hline Nitazoxanide & N/A & $\begin{array}{l}\text { A drug that may inhibit viral protein } \\
\text { expression }\end{array}$ & $\begin{array}{l}\text { Various helminthic, Protozoal and } \\
\text { Viral infection-caused diarrhea }\end{array}$ \\
\hline
\end{tabular}

available. An economic and efficient therapeutic strategy is to repurpose existing drugs.

\section{Antiviral \& Anti-inflammatory Drugs}

Based on genomic arrangement data combined with protein structure demonstrating, mainstream researchers has had the option to quickly react with a recommended rundown of existing medications with restorative potential for COVID-19. Table 1 gives a synopsis of such medications along with potential components of activities for their exercises. Barcitinib was proposed in view of its calming impact and conceivable capacity to lessen viral entry. A fixed portion of the counter HIV mix, lopinavir-ritonavir, is presently in clinical preliminaries with Arbidol or Ribavirin [22]. Remdessivir, created by Gilead Sciences Inc., was recently tried in people with Ebola infection illness and has demonstrated guarantee in creature models for MERS and SARS. The medication is as of now being concentrated in stage III clinical preliminaries in both China and the USA. Favipiravir, a purine nucleoside prompting off base viral RNA synthesis, was initially evolved by Toyama Chemical of Japan, and has as of late been affirmed for a clinical preliminary as a medication to treat COVID-19 [22-32].

\section{Anti-malarial drugs}

Chloroquine's potential in treating COVID-19 is picking up footing in the clinical network. Chloroquine can raise the $\mathrm{pH}$ of endosomes, vesicles inside cells that are captured as purposes of section by infections. Endosomes have a somewhat acidic $\mathrm{pH}$, which encourages this procedure. The chloroquine can raise endosomic $\mathrm{pH}$ marginally, which forestalls combination and prevents the infection from entering the phone. Chloroquine may likewise square catalysts associated with the combination between the infection and lung cells or obstruct the viral replication process [33].

\section{Blood Plasma or Antibody Treatment}

Antibodies are a significant part in have resistant reactions to viral pathogens. As a result of their one of a kind development process, antibodies can advance to be exceptionally explicit to viral antigens. Doctors and specialists have been depending on such high explicitness in their mission to comprehend have viral communication and viral pathogenesis components and to discover potential solutions for viral contamination and illness. The epidemiological effect of viral maladies, joined with the rise and reappearance of some infections, and the troubles in recognizing powerful treatments, have urged a few investigations to grow new restorative procedures for viral contaminations. In this specific circumstance, the utilization of immunotherapy for the treatment of viral sicknesses is expanding. One of the procedures of immunotherapy is the utilization of antibodies, especially the Monoclonal Antibodies (mAbs) and multi-explicit antibodies, which tie legitimately to the viral antigen and achieve initiation of the safe framework.

\section{Spike Protein-Based Vaccines Therapies}

The significant role of Spike Protein (S protein) in receptor authoritative and layer combination demonstrate that immunizations dependent on the spike protein could initiate antibodies to square infection official and combination or kill infection contamination. Among every single auxiliary protein of SARS-CoV, spike protein is the primary antigenic part that is answerable for initiating host resistant reactions, killing antibodies or potentially defensive insusceptibility against infection disease. Spike protein has in this manner been chosen as a significant objective for coronavirus immunization 
and hostile to viral turn of events. An examination of these methodologies is given in (Table 2).

\section{Phytochemicals or Indian Medicinal Plants Therapy}

Indian customary therapeutic and phytochemicals are considered as probably the most established treatment in mankind's history and it assumes a significant job in experiencing worldwide medicinal service's needs.

A large portion of the therapeutic plant contained synthetically dynamic phytochemical gathering. Phyto- chemical compound fills in as a legend and - protein at the site where it was known to engage in have cell official. Their coupling connections are more steady than with that of as of late accessible medication. Thus, it was likewise observed that these atoms join to those locales of ACE2 which were engaged with serving a mode of viral entry [34-39]. Some of the myricetin, scutellarein, and phenolic mixes fill in as characteristic inhibitors against the SARS-Covid19. They show the distinctive antiviral components against SARS-CoV that incorporate repressing the viral $3 \mathrm{CL}$ protease and obstructing the movement of viral RNA-subordinate RNA

Table 2: Spike protein-based vaccines and antiviral therapies against SARS-CoV.

\begin{tabular}{|l|l|l|}
\hline Vaccines* & Advantages & Disadvantages \\
\hline $\begin{array}{l}\text { Full-length S } \\
\text { protein }\end{array}$ & $\begin{array}{l}\text { Induces effective neutralizing-antibody and T-cell } \\
\text { responses as well as protective immunity }\end{array}$ & $\begin{array}{l}\text { Might induce harmful immune responses that } \\
\text { cause liver damage or enhanced infection }\end{array}$ \\
\hline DNA-based & $\begin{array}{l}\text { Easier to design, Induces immunoglobulin G, Neutralizing- } \\
\text { antibody and T-cell responses and/or Protective immunity }\end{array}$ & $\begin{array}{l}\text { Might have low efficacy in humans, } \\
\text { Repeated doses may cause toxicity }\end{array}$ \\
\hline Viral vector-based & $\begin{array}{l}\text { Induces neutralizing-antibody responses, Protective } \\
\text { immunity and/or T-cell responses }\end{array}$ & $\begin{array}{l}\text { Might induce ADE effect, Possibly present } \\
\text { pre-existing immunity }\end{array}$ \\
\hline $\begin{array}{l}\text { Recombinant S } \\
\text { protein-based }\end{array}$ & $\begin{array}{l}\text { Induces high neutralizing-antibody responses and } \\
\text { Protective immunity }\end{array}$ & $\begin{array}{l}\text { Mainly humoral responses, Need repeated } \\
\text { doses and Adjuvants }\end{array}$ \\
\hline RBD & $\begin{array}{l}\text { Induces highly potent neutralizing-antibody and T-cell } \\
\text { responses and Protective immunity }\end{array}$ & Not identified \\
\hline DNA-based & $\begin{array}{l}\text { Induces neutralizing-antibody and T-cell responses and/or } \\
\text { Protective immunity }\end{array}$ & $\begin{array}{l}\text { Induces low responses, Might not neutralize } \\
\text { mutants }\end{array}$ \\
\hline Viral vector-based & $\begin{array}{l}\text { Induces neutralizing-antibody responses, Protective } \\
\text { immunity and/or T-cell responses }\end{array}$ & $\begin{array}{l}\text { Possible genomic integration of foreign DNA, } \\
\text { Viral vector instability }\end{array}$ \\
\hline $\begin{array}{l}\text { Recombinant RBD } \\
\text { protein-based }\end{array}$ & $\begin{array}{l}\text { Safer and more effective than other RBD vaccines, } \\
\text { Induces neutralizing-antibody and T-cell responses, } \\
\text { Protective immunity and Cross protection }\end{array}$ & Needs repeated doses and Adjuvants \\
\hline
\end{tabular}

Table 3: Phytochemical source and mode of action.

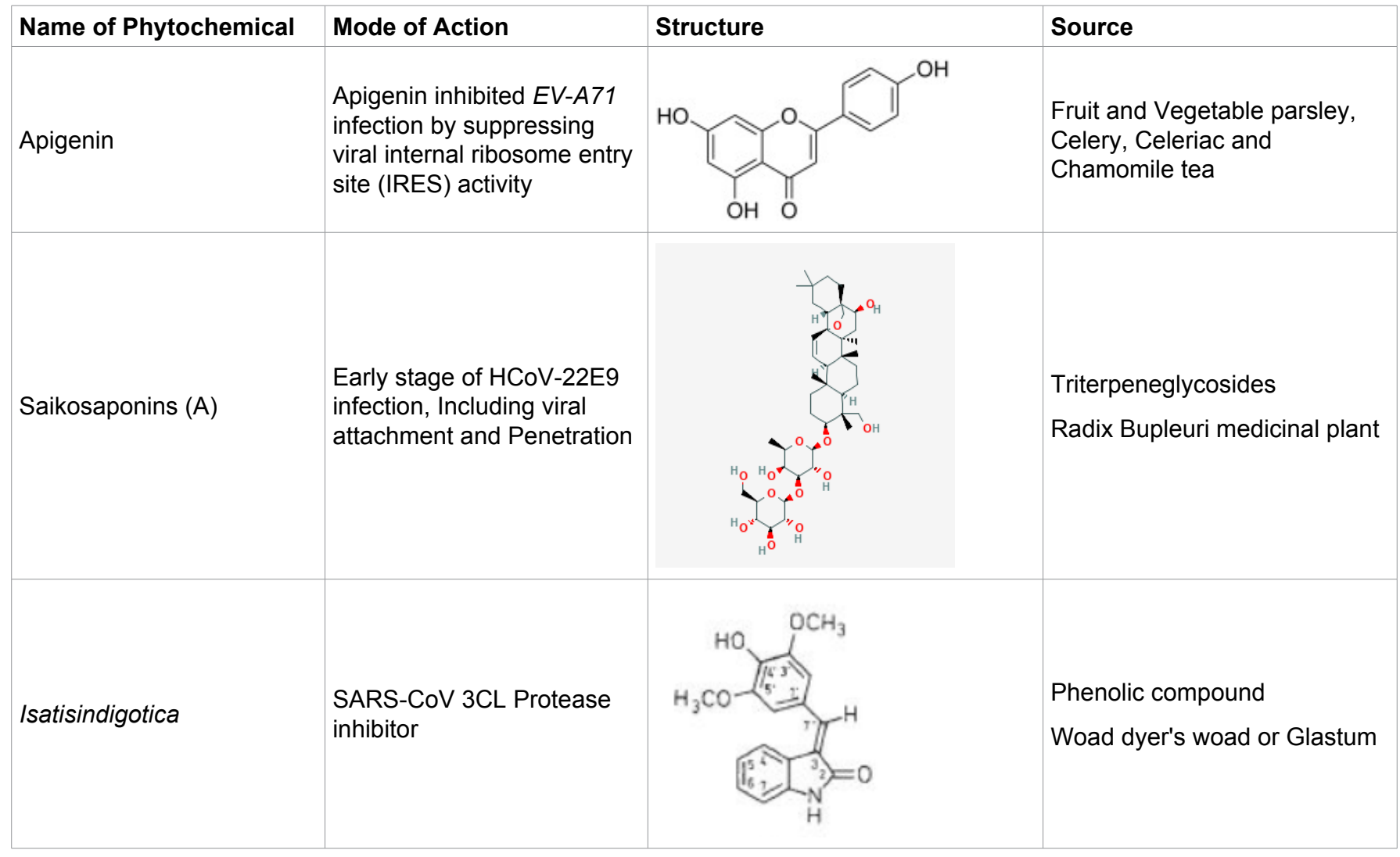




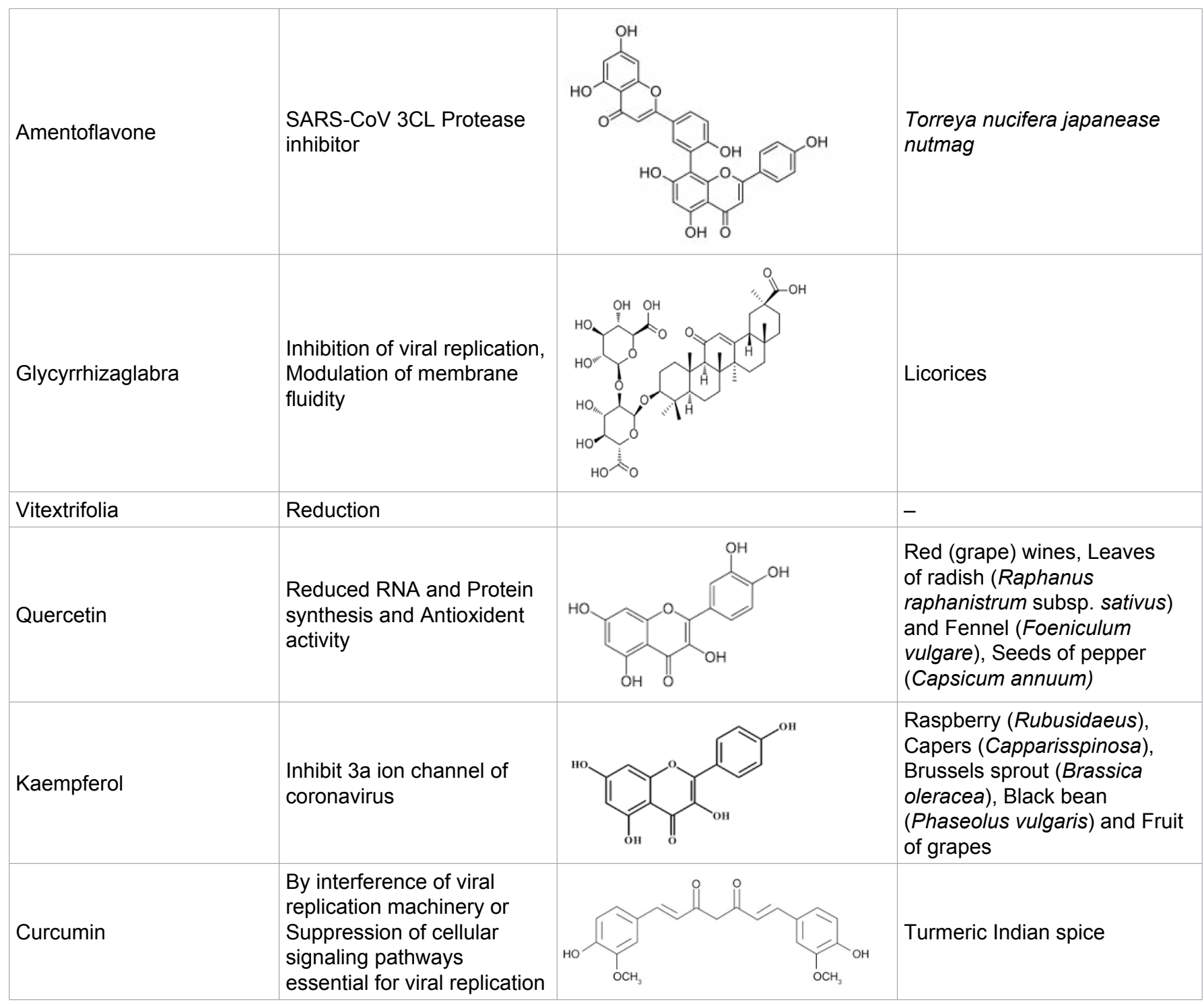

Table 4: Source and Immune activity of different nutraceutical ingredients.

\begin{tabular}{|c|c|c|c|}
\hline $\begin{array}{l}\text { Name of Nutraceutical } \\
\text { ingredient }\end{array}$ & Natural recourse & Immune activity & $\begin{array}{l}\text { Mechanism of Booster } \\
\text { immune system }\end{array}$ \\
\hline Multi-Vitamin & $\begin{array}{l}\text { - } \quad \text { Meat, Poultry, Fish and Beans } \\
\text { - } \quad \text { Carrots, Sweet potatoes, } \\
\text { Spinach, Kale } \\
\text { - } \quad \text { Meat, Poultry, Fish } \\
\text { - } \quad \text { Nuts, Seeds, Vegetable oils }\end{array}$ & $\begin{array}{l}\text {-Anti viral activity } \\
\text {-Anti Microbial } \\
\text {-Retinal and Cardiovascular } \\
\text {-Auto-immune Diseases }\end{array}$ & $\begin{array}{l}\text { - Enhancement the Surrogate } \\
\text { markers } \\
\text { - Increase in CD4+ T cell } \\
\text { percentages, Natural killer } \\
\text { cell activity }\end{array}$ \\
\hline Curcumin & Indian Haldi & $\begin{array}{l}\text { Hepatitis viruses, Influenza } \\
\text { viruses }\end{array}$ & $\begin{array}{l}\text { By interference of viral } \\
\text { replication machinery or } \\
\text { Suppression of cellular } \\
\text { signaling pathways essential } \\
\text { for viral replication }\end{array}$ \\
\hline Vitamin C & $\begin{array}{l}\text { Kiwi fruit, Citrus fruit, Strawberries, } \\
\text { Red bell peppers }\end{array}$ & & \\
\hline Vitamin D & $\begin{array}{l}\text { Fortified dairy products, Fatty fish, } \\
\text { Exposure in Sunlight, Oranges }\end{array}$ & Boosts mucosal defenses & Immunomodulation \\
\hline Garlic & Garlic root & $\begin{array}{l}\text { Viral activity } \\
\text { anticancerogenic, Anti- } \\
\text { inflammatory }\end{array}$ & Produce alliin a \\
\hline
\end{tabular}

polymerase 29. Regular mixes successfully forestall the beginning time of HCoV-22E9 contamination, including viral connection and infiltration. saikosaponins (A, B2, C, and $D$ ), which are normally happening triterpene glycosides detached from therapeutic plants, for example,
Bupleurum spp. Heteromorpha spp., and Scrophularia scorodonia apply antiviral action against HCoV-22E9. Normal inhibitors against the SARS-CoV catalysts, for example, the nsP13 helicase and $3 \mathrm{CL}$ protease, have been distinguished also and incorporate myricetin, scu- 
tellarein, and phenolic mixes from Isatisi ndigotica and Torreya nucifera [40-44].

W. somnifera compound found in Indian medicinal plant Ashwagandha that content Withanone, That docked very well in the binding interface of AEC2-RBD complex, and found interruption of electrostatic interactions between the RBD and ACE2 would block or weaken COVID-19 entry and its subsequent infectivity [45].

The Curcumin is the integral part of Indian kitchen this compound directly involve either a direct interference of viral replication machinery or suppression of cellular signaling pathways essential for viral replication, such as PI3K/Akt, NF-Kb [21]. Inosine Monophosphate Dehydrogenase (IMPDH) enzyme due to rate-limiting activity in the de novo synthesis of guanine nucleotides is suggested as a therapeutic target for antiviral compounds. Several other compounds like Glycyrrhizin inhibits SARS-Associated Coronavirus (SARS-CoV) replication in Vero cells with a selectivity index of 67 [45].

Studies revels kaempferol has high bioavailability. In particular, The fact that these drugs not only block the 3a channel, thus counteracting virus production, but that they also interfere with other steps of the viral life cycle emphasizes the importance of multi-target phytochemical. The glycosides of kaempferol seem to be highly potent candidates for development as anti-coronaviral agents [46-51] (Table 3).

\section{Immune Boost Therapy by Dietary Supplements}

The number of cases increment step by step far and wide on the grounds that this sickness can spread from individual to individual by means of little beads from nose or mouth when an individual with COVID-19 hacks or exhales. People with covid-19 have a wide scope of manifestations like trouble of breathing, some other respiratory condition, kidney disappointment and prompts demise. Invulnerable lift diet Nutraceutical compound (Table 4) helps to support safe framework.

The different investigations delights the enhancement of Curcumin, Vitamin D, Vitamin C and follow component retinol, $\beta$-carotene, thiamine, riboflavin, niacin, pyridoxine, folate, iron, zinc, copper, selenium, iodine, calcium, magnesium, and nutrients B12, C, D, and $E$ to sound grown-ups in the network. Nutrient inadequacy, an expansion in CD4+ $\mathrm{T}$ cell rates, common executioner cell movement, mitogenic reactions, and IL-2/IL-2 receptor articulation in the gathering that got the enhancement.

The avoidance rule distributed by focal infection control and World wellbeing association help network to forestall this circumstance. The accompanying measures recommended by the wellbeing organizations.

1. Maintain the separation with individuals at rent $6 \mathrm{ft}$ in light of the fact that might be spread by individuals who are not demonstrating side effects.

\section{Avoid the open vehicle.}

3. Avoid the administers voyages and if fundamental, if you don't mind remain in isolate for 14 .

4. Wash or sterilize the hand much of the time.

5. Cleaning the home and surfaces with cleanser and water lessens number of germs, soil and contaminations on a superficial level.

6. Avoid touching your eyes, nose, and mouth with unwashed hands.

7. Everyone should wear a material face spread when they need to go out in the open, for instance to the market or to get different necessities.

It's the ideal opportunity for all the residents to hold hands together Create mindfulness, follow great eating regimen excise to by rehearsing self-cleanliness and social removing is just an approach to win this fight.

\section{Conclusion}

There is also no magic pill to boost our immune systems to help us fight the disease if we are infected. Due to high bioavailability, efficacy phytochemicals is a promising preventive option in this situation. Include phytochemical rich food like curcumin, Ginger below the daily intake limit could be prevent the un-effected population of world by the pandemic situation. Author concludes the therapies discussed in this article are subject to clinical trials and FDA approvals. Until the scientist not gets any clinical therapy only prevention is better approach.

\section{Conflicts of Interest}

The authors report no conflicts of interest in this work.

\section{Acknowledgements}

I am thankful to our coworkers, Professor Archana Panday and the Department of chemistry Dr. Hari Singh Gour University, India providing an opportunity to work here as a research Scholar.

\section{References}

1. Chaolin Huang, Yeming Wang, Xingwang Li, Lili Ren, Jianping Zhao, et al. (2020) Clinical features of patients infected with 2019 novel coronavirus in Wuhan, China. Lancet 395: 497-506.

2. Cyranoski D (2020) Did pangolins spread the China coronavirus to people.

3. Nimesh Singh, Archna Panday (2020) Corona virus: A review article to identify novel drug for treatment. IJSR 9: 2319-7064.

4. Jasper Fuk-Woo Chan, Shuofeng Yuan, Kin-Hang Kok, Kelvin Kai-Wang To, Hin Chu, et al. (2020) A familial cluster of pneumonia associated with the 2019 novel coronavirus indicating person-to-person transmission: A study of a family cluster. Lancet 395: 514-523.

5. Enjuanes L, Almazan F, Sola I, Zuniga S (2006) Biochemi- 
cal aspects of coronavirus replication and virus-host interaction. Annu Rev Microbiol 60: 211-230.

6. Perlman S, Netland J (2009) Coronaviruses post-SARS: Update on replication and pathogenesis. Nat Rev Microbio 7: 439-450.

7. Graham RL, Baric RS (2010) Recombination, reservoirs, and the modular spike: Mechanisms of coronavirus cross-species transmission. J Virol 84: 3134-3146.

8. Li F (2013) Receptor recognition and cross-species infections of SARS coronavirus. Antivir Res 100: 246-254.

9. https://www.worldometers.info/coronavirus/

10. (2020) Morningstar's view: The impact of coronavirus on the economy.

11. (2020) Health preparedness and trade affect COVID-19 exposure.

12. Li-sheng Wang, Yi-ru Wang, Da-wei Ye, Qing-quan Li (2020) Review of the 2019 Novel Coronavirus (COVID-19) based on current evidence. International Journal of Antimicrobial Agents.

13. Organization WH (2020) Coronavirus disease (COVID-19) Situation Report-40.

14. Chan JF, To KK, Tse H, Jin DY, Yuen KY (2013) Interspecies transmission and emergence of novel viruses: lessons from bats and birds. Trends Microbiol 21: 544-555.

15. Muhammad Adnan Shereen, Suliman Khana, Abeer Kazmi, Nadia Bashira, Rbeea Siddiquea (2020) COVID-19 infection: Origin, transmission, and characteristics of human coronaviruses. Journal of Advance Research 24: 91-98.

16. Yvonne Xinyi Lim, Yan Ling Ng, James P Tam, Ding Xiang Liu (2016) Human Coronaviruses: A review of virus-host interactions.

17. https://www.ncbi.nlm.nih.gov/books/NBK554776/figure/article-52171.image.f1/

18. Salman H, Bergman M, Bessler H, Punsky I, Djaldetti M (1999) Effect of a garlic derivative (alliin) on peripheral blood cell immune responses. International Journal of Immunopharmacology 21: 589-597.

19. ht t p s : / / twitter. com/AFPgraphics/status/1246330114171961358/photo/1

20. Reinhart KM, Talati R, White CM, Coleman Cl (2009) The impact of garlic on lipid parameters: A systematic review and metaanalysis. Nutr Res Rev 22: 39-48.

21. Eilat-Adar S, Sinai T, Yosefy C, Henkin Y (2013) Nutritional recommendations for cardiovascular disease prevention. Nutrients 5: 3646-3683.

22. (2020) The Efficacy of lopinavir plus ritonavir and Arbidol against novel coronavirus infection (ELACOI).

23. Peter Richardson, Ivan Griffin, Catherine Tucker, Dan Smith, Olly Oechsle, et al. (2020) Baricitinib as potential treatment for 2019-nCoV acute respiratory disease. Lancet 395: e30-e31.

24. Mifsud EJ, Hayden FG, Hurt AC (2019) Antivirals targeting the polymerase complex of influenza viruses. Antiviral Res 169.

25. Sheahan TP, Sims AC, Leist SR, Schafer A, Won J, et al. (2020) Comparative therapeutic efficacy of remdesivir and combination lopinavir, ritonavir, and interferon beta against MERS-CoV. Nat Commun.

26. Zeldin RK (2003) Pharmacological and therapeutic pro- perties of ritonavir-boosted protease inhibitor therapy in HIV-infected patients. J Antimicrob Chemother 53: 4-9.

27. Guo D (2020) Old weapon for new enemy: Drug repurposing for treatment of newly emerging viral diseases. Virol Sin.

28. (2020) Therapeutic options for the 2019 novel coronavirus (2019-nCoV).

29. Wu Y (2020) Compensation of ACE2 function for possible clinical management of 2019-nCoV-induced acute lung injury. Virol Sin.

30. Jared S Morse, Tyler Lalonde, Shiqing Xu, Wenshe Ray Liu (2020) Learning from the past: Possible urgent prevention and treatment options for severe acute respiratory infections caused by 2019-nCoV. Chem Bio Chem 21: 730738.

31. (2020) Chloroquine for COVID-19: Cutting through the hype.

32. Zhou Y, Simmons G (2012) Development of novel entry inhibitors targeting emerging viruses. Expert Rev Anti Infect Ther 10: 1129-1138.

33. De Lano W (2002) The PyMOL Molecular Graphics System.

34. Atala B Jena, Namrata Kanungo, Vinayak Nayak, GBN Chainy, Jagneshwar Dandapat (2020) Catechin and Curcumin interact with corona (2019-nCoV/SARS-CoV2) viral $S$ protein and ACE2 of human cell membrane: Insights from Computational study and implication for intervention.

35. Chandel V, Raj S, Rathi B, Kumar D (2020) In silico identification of potent COVID-19 main protease inhibitors from fda approved antiviral compounds and active phytochemicals through molecular docking: A drug repurposing approach. Preprints.

36. (2020) European review for medical and Pharmacological sciences 24: 4030-4034.

37. Acharya Balkrishna, Subarna Pokhrel, Jagdeep Singh, Anurag Varshney (2020) Withanone from withania somnifera may inhibit novel coronavirus (Covid-19) entry by disrupting interactions between viral S-protein receptor binding domain and host Ace 2 receptor.

38. Steinmann J, Buer J, Pietschmann T, Steinmann E (2013) Anti-infective properties of epigallocatechin-3-gallate (EGCG), a component of green tea. $\mathrm{Br} \mathrm{J}$ Pharmacol 168: 1059-1073.

39. Dimas Praditya, Lisa Kirchhoff, Janina Bruning, Heni Rachmawati, Joerg Steinmann, et al. (2019) Anti-infective properties of the golden spice curcumin. Front Microbiol.

40. Mathew D, Hsu WL (2018) Antiviral potential of curcumin. Journal of Functional Foods.

41. Kevin P High (2001) Nutritional strategies to boost immunity and prevent infection in elderly individuals. Clin Infect Dis 33: 1892-1900.

42. Zorofchian Moghadamtousi S, Hajrezaei M, Abdul Kadir $\mathrm{H}$, Zandi K (2013) Loranthus micranthus Linn: Biological activities and phytochemistry. Evidence-Based Complementary and Alternative Medicine.

43. Thomas T Yoshikawa, Kevin P (2001) Nutritional strategies to boost immunity and prevent infection in elderly individuals. High Clinical Infectious Diseases 33: 1892-1900.

44. (2013) World Health Organization.

45. SY Li, C Chen, HQ Zhang, HY Guo, H Wang, et al. (2005) 
Identification of natural compounds with antiviral activities against SARS-associated coronavirus. Antivir Res 67: 1823.

46. CW Lin, FJ Tsai, CH Tsai, CC Lai, L Wan, et al. (2005) Anti-SARS coronavirus $3 \mathrm{C}$-like protease effects of Isatisindigotica root and plant-derived phenolic compounds. Antivir Res 68: 36-42.

47. C Fiore, M Eisenhut, R Krausse, E Ragazzi, D Pellati, et al. (2008) Antiviral effects of Glycyrrhiza species. Phytother Res 22: 141-148.

48. J Liou, CY Cheng, KW Yeh, YH Wu, WC Huang (2018) Protective effects of casticin from vitextrifoliaalleviatee osi- nophilic airway inflammation and oxidative stress in a murine asthma model. Front Pharmacol 635.

49. Salima Lalani, Chit Laa Poh (2020) Flavonoids as Antiviral agents for enterovirus A71 (EV-A71). Viruses 12: 184.

50. Cinatl J, Morgenstern B, Bauer G, Chandra P, Rabenau H, et al. (2003) Glycyrrhizin an active component of liquorice roots, and replication of SARS-associated coronavirus. The Lancet 14: 2045-2046.

51. Liang-Tzung Lin, Wen-Chan Hsu, Chun-Ching Lin (2014) Antiviral natural products and herbal medicines. J Tradit Complement Med. 